\title{
Collaborative Governance in Peat Restoration in Ogan Komering Ilir District, South Sumatra Province
}

\author{
Arif Rahman Hakim ${ }^{1}$, Sri Suwitri ${ }^{2}$, Endang Larasati ${ }^{3}$, Ida Hayu Dwimawanti ${ }^{4}$ \\ \{a12ifhakim@gmail.com ${ }^{1}$, sri_suwitri@yahoo.co.id ${ }^{2}$, larasati57@ymail.com ${ }^{3}$,ida2hades3@gmail.com $\left.{ }^{3}\right\}$ \\ Faculties of Social and Political Sciences, Diponegoro University, Indonesia \\ Faculty of Social and Political Sciences, Tidar University, Magelang ${ }^{2}$ \\ Faculties of Social and Political Sciences, Diponegoro University, Indonesia \\ Faculties of Social and Political Sciences, Diponegoro University, Indonesia ${ }^{4}$
}

\begin{abstract}
This study analyzes collaborative governance in peat restoration policies. Analysis of collaborative governance in peat restoration policies uses the theory of Ratner's Collaborative Governance Stages (2012), which includes Identification of Obstacles and Opportunities, Debating Strategies for Influence, Planning Collaborative Actions. The method used is descriptive qualitative method. The data collection technique is done by interviews, observation and documentation. Data analysis was used in three stages, namely data condensation, data presentation and drawing conclusions. The results show that the Peat Collaboration in Ogan Komering Ilir District, South Sumatra Province is still in the pilot phase and provides an initial basis for developing future peat of restoration policies. There are obstacles in the integration of ecosystem-based restoration activities, namely the difference in interests between restoration mandate holders (local government and Peat Restoration Agency / BRG) and land managers (community and company concessions). The Implementation and management of peat restoration are requiring strategic collaboration for the development of effective, equitable, and sustainable peat restoration. Strategies need to be developed so that each stakeholder has the same authority in determining policies and implementation actions for peat restoration to follow peat restoration in the present and future. The follow-up to forming a permanent forum is needed in a flexible manner, by avoiding a strict hierarchical structure or using a horizontal organization, so that it can accommodate and make optimal use of various potential stakeholders.
\end{abstract}

Keywords: Collaborative Governance, Peat Restoration, Ogan Komering Ilir

\section{Introduction}

Indonesia has approximately 14.9 million hectares of peat land [1]. With this area, Indonesia ranks fourth as the country with the largest peat land in the world after Canada (170 million hectares), Russia (150 million hectares), and the United States (40 million hectares) [2]. Peat lands play a big role in absorbing carbon and maintaining hydrological systems. The characteristics of damaged and oxidized peat make the International Government and Indonesia pay great attention to the management and protection of peat ecosystems. 
Peat is an accumulation of organic materials that do not fully decomposition due to submerged water. This anaerobic condition causes a low rate of decomposition compared to the rate accumulation of organic matter. Due to its wide scope, the area forms a distinctive ecosystem, namely peat land and swamp forests [3]. Government Regulation No. 71 in 2014 as the changing of Government Regulation No. 57 in 2016, as well as the theory from [4]. These are relate to the Protection and Management of Peat Ecosystems adopted the term peat as "organic material formed naturally from the remains of imperfectly decomposed plants with a thickness of 50 (fifty) $\mathrm{cm}$ or more and accumulated in swamps" (Article 1 paragraph 2 PP No. $71 / 2014$ junco PP 57/2016). Peat swamp ecosystems are defined as "peat elemental order which is a whole whole unit that influences each other in shaping its balance, stability, and productivity".

South Sumatra province has the second largest peat land in Sumatra Island after Riau Province. The area covers $16.3 \%$ of the area of South Sumatra Province. The peat area is spread over 5 (five) districts namely Ogan Komering Ilir Regency with an area of 768,501 ha, Musi Banyuasin with peat area of 340,604.48 ha, Banyuasin with an area of 252,706.52 ha, Musi Rawas with an area of 34,126.00 ha and Muara Enim with an area of 24,104.00 ha (Peat Restoration Agency).

In 2015, 33\% of the forest and land burned were in peat land (Peat Restoration Agency). Forest and land fires have been going on for three months. Even economically, the World Bank estimates the impact of losses reaching IDR 221 Trillion. These losses do not include long-term losses such as health problems for children exposed to the smoke and its future impacts.

Indonesia's commitment to contribute to the reduction of world carbon emissions was also demonstrated by issuing [5]. This press is about the Peat Restoration Agency, a nonstructural body that directly responds under the President to carry out the restoration and design of peat governance in the future. This is especially important because of the vitality of peat and is at the root of the problems of forest and peat land fires over the years.

Since 2016, the government has established a Peat Restoration Agency abbreviated as (BRG) tasked with coordinating and facilitating peat restoration programs. BRG became a facilitator between the ministry and related agencies to realize the target of restoration of 2 million hectares of peat land damaged by forest and land fires abbreviated as (karhutla). These are classified in seven priority provinces, namely South Sumatra, Riau, Jambi, West Kalimantan, Central Kalimantan, South Kalimantan and Papua based on [5] on Peat Restoration Agency. Based on BRG Head Decree No.05/BRG/KPTS/2016 on Peat Restoration Indicative Map Determination, the area of restoration target in seven provinces is 2 million hectares. As much as $30 \%$ of the 2 million hectares of peat land targeted to be carried out in 2016 , $20 \%$ of peat land restoration priorities will be achieved in 2017, 2018, and 2019 respectively, as well as $10 \%$ in 2020 [6].

Effective collaboration is realized from various processes such as communication, cooperation, and flexibility. The meaning of collaboration is cooperation, or communal work. The word collaboration comes from the Latin, collaborare, which means to work together. The collaboration of the parties for peat restoration means the cooperation of the parties, such as the government, private, community to manage peat areas, namely areas designated as cultivation and peat protected areas. This study examines the stages of collaborative governance in peat restoration in Ogan Komerig Ilir Regency of South Sumatra Province. 


\subsection{Literature review}

\section{A. Collaborative governance}

Collaborative governance is an essentially of a management process and formulation of public policy decisions involving actors who constructively come from various levels, whether elements of government or public institutions, private institutions, as well as communities that collaborate to achieve public goals.

[7] stated that Collaborative governance is a governance arrangement in which one or more public institutions directly engage non-governmental actors in a formal, consensusoriented, and consultative collective policymaking process in order to create or implement public policy, manage public programs or assets. Collaborative governance is a new strategy in governance that makes different policymakers gathers in the same forum to create a common consensus.

Collaborative governance develops in an era of governance concepts, where government was just one of the actors in public policy and public services. The government is not the only executor of a good bureaucracy but there are other stakeholders, both the private and community sectors.

Collaborative governance is an instrument used to solve problems, which creates "shared ownership" of the problem. Various actors have different perspectives on looking at problems, so collaborative governance acts as an intermediary so that actors can formulate a common understanding of a problem [8].

According to [9] in the collaborative governance assessment, there were three focus phases or three stages, which is the process of collaboration in governance, can be seen in the following figure:

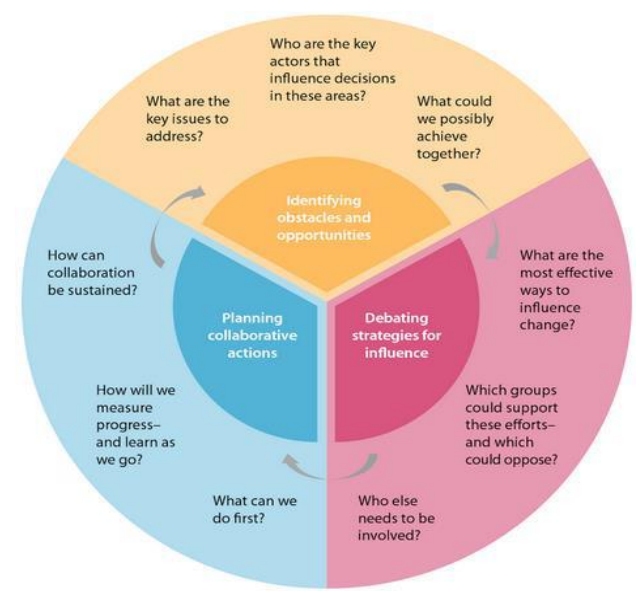

Fig.1, Collaborative Governance Assessment, Three stages of collaborative governance assessment and action planning (Ratner, 2012: 5) 
Based on the image, it can be known that three phase focuses or three stages include as follows:

1. Identifying Obstacles and Opportunities

This first phase is the listening phase. At this stage, the stakeholders who collaborate identify the different types of obstacles faced during the collaboration process. At this stage, each stakeholder explains each other about the issue, and the other stakeholders listen to each other on every issue explained by each stakeholder involved. Then take into account the opportunities in solving each problem that has been identified, such as the solution in 2016 settlement. Each stakeholder has the same authority to set policy on every issue that has been identified and take into account the opportunities in the form of results obtained from each party involved. This phase is a phase of listening to each other about problems and opportunities to be able to take advantage of every problem described by each stakeholder.

2. Debating Strategies for Influence

In this phase focusing on dialogue or discussion, stakeholders involved in the collaboration conduct a dialogue or discussion about the obstacles described in the first phase. Discussions conducted by each of the stakeholders involved include discussions about the steps chosen as the most effective steps to solve the problem. Furthermore, discuss the parties who are able to support the resolution of the problem in collaboration that teach explained.

3. Planning Collaborative Actions

This phase is characterized by the efforts of the stakeholders or policymakers involved to begin planning the implementation of each strategy that has been carried out in the previous phase. This includes, among other things, the initial steps that must be taken in the collaboration process between stakeholders, identifying the measurement of each process taken and determining steps to maintain the collaboration process to continue in the long term.

\section{B. Peat Restoration}

Peat Restoration is an effort to protect and manage peat ecosystems, which include the protection, recovery, and utilization of natural resource wealth in the form of peat ecosystems, which are carried out sustainably and wisely to ensure continuity of their function, in order to provide benefits in supporting human life [10]. Peat restoration is a process to restore the ecological function of peat lands, while improving the welfare of communities affected by shrinking peat lands. If understood in terms of definition, restoration is the same effort of the disaster management stage called rehabilitation. However, at the restoration stage, there are also mitigation elements in the 5 steps of forest and peat land restoration.

According to [11] presented steps in restoring peat namely: 1. mapping peat; 2 . determine the type, perpetrator, and time span of restoration implementation, 3. wetting peat (rewetting); 4. Planting peat land (vegetation); 5. Revitalize livelihood resources or empower local communities.

The first step is mapping forests and peat lands. Peat land mapping is indispensable in order to determine the location of shrinking peat and know its type and depth. Mapping forests and peat lands can help reduce the reduction of peat land area due to land conversion through appropriate policies to base on the findings of peat land studies. This mapping is also a tricky first step, as different peat conditions require different types of restoration, for example in determining the location of the construction of canal partitions to regulate water content. In 
order to make proper restoration efforts, the community must use the right methodology as well. As the government did, it created the Peat Hydrological Union abbreviated as (KHG), to facilitate peat protection and management.

The second step, determining the type, perpetrator, and time span of the restoration implementation, after doing peat mapping, the restoration actors can determine the type of restoration according to peat conditions. There are peat that go through the process of wetting first there are also directly replanted, and some are also through the process of peat cleaning, for example peat exposed to pieces of plant waste, leaves, twigs, or wood then peat must be cleaned first. After determining the type of restoration, then determine which stakeholders are involved. Then determine the time span of the restoration implementation, for example, which the government sets, now determines the time span for five years.

The third step is to wet the peat (rewetting). Wetting peat land needs to be done to keep peat moist and maintained its benefits as well so that peat is difficult to burn. In this step, all we do is organize the water. Organize water by creating canal partitions, to keep water in peat land and help areas experiencing water drought. Related to peat land wetting measures, [2] suggested that peat land ecosystem areas be divided into 2 areas namely: non-cultivated areas and cultivation areas. The non-cultivated area consists of (a) green paths along the coast and river embankments and (b) rain-ad areas that are at least $1 / 3$ of the total area. The area that used as a rain-covered area is part of the peat dome so that it should be a conservation area. Peat dome serves as water storage (reservoir) that can supply water for the surrounding area, especially in the dry season, both for drinking water and farming. In the rainy season, this area serves as an excessive water container to reduce the risk of flooding for the surrounding area. This is possible because peat has a very large water holding power that is up to 13 times its dry weight. Protection of the rainy area will ensure the surrounding area becomes more productive.

The fourth step, replanting peat land (vegetation); After the rewetting process is complete then peat land can be planted by peat-friendly seasonal plants such as pineapple, cocoa, coffee and so on [2]. Peat land planting to maintain the sustainability of peat ecosystems, strengthens canal partitions, and protects peat land from the erosion of canal water flows.

The last step is to empower the local economy. Not only does it stop at ecological recovery and replanting, but also restoration must pay attention to the economic empowerment of local communities, in order to create good natural resources and human resources.

\section{Finding and Discussion}

\section{A. Peat Restoration in Ogan Komering Ilir Regency of South Sumatra Province}

Peat Restoration Program is through Auxiliary Task Scheme 2018. The implementation of peat restoration task force activities in 2018 began with the receipt of the Budget Implementation Task Force (DIPA) in May 2018, where the Office of Environment and Land of South Sumatra Province was appointed to be the Implementing Task Force abbreviated as (Satker) which is automatically designated as the Budget User Power.

Effectively, the implementation of the new Peat Restoration Task Force fund can be started in August 2018, given the Work Plan \& Budget of the Ministry of State /Agency (RKA/KL) received, still needs to be revised according to the implementation to be carried out in the field. 
In its technical implementation, the Office of Environment and Land of South Sumatra Province divides the activities into 3 (three) main activities, which each activity is appointed by a Commitment Making Officer from 3 (three) different agencies, namely:

1. South Sumatra Provincial Water Resources Management Office for Rewetting activities;

2. South Sumatra Provincial Forest Service for Vegetation activities;

3. Department of Environment and Land of South Sumatra Province for Revitalization as well as coordination and facility activities

\section{B. Collaborative Governance into Peat Restoration} as follows:

Collaborative Governance in Peat Restoration based on [9] stages, could be described

\section{Identifying Threats and Opportunities}

The Regional Peat Restoration Team (TRGD) of South Sumatra initiated the identification stages for peat restoration by holding coordination and dialogue or Accelerated Engineering Meeting in carrying out tasks. In this Field of 3 Deputies that classified into (Deputy for Education, Socialization, Participation and Partnership) and 4 Ministry (Deputy for Research and Development) of the Peat Restoration Agency abbreviated as (BRG) of Indonesia Republic (RI).

Participants of the meeting consisting of Deputy III, IV BRG, The Working Group of Deputy III and IV of BRG South Sumatra. Subsection Head of Working Group III and IV BRG South Sumatra, Dynamicator Deputy III of South Sumatra Region, Coordinator, Deputy Coordinator, Head and Secretary of TRGD South Sumatra, Head of South Sumatra Environment and Land Office, Head of South Sumatra/ Head of Field PMD Office in charge. Head of Chairman of TRGD Expert Team of South Sumatra, Team Experts of Faculty of Agriculture Sriwijaya University, Head Project Manage Sendang ZSL, Chairman of Tropical Forest Alliance 2020 Forum. CEO of Belantara Foundation, Director of IDH, APHI, GAPKI, Mongabay (Media), Chairman of HMI Palembang Branch, Head of Rumah Zakat Indonesia South Sumatra Region, Chairman of Bina Ilmi Foundation, Village Facilitator 4 People and Regional Peat Restoration Team (TRGD) South Sumatra. TRGD Coordinator of South Sumatra led and opened the meeting held at Swarnadwipa Hotel, Jalan Tasik Palembang, Thursday (03/21/2019).

Barriers to peat restoration include accuracy and at least peat land map data, long and unpredictable droughts, year-over-year budgets declining, and peat restoration requiring support from all stakeholders. Opportunities in solutions for peat restoration were found in the Regional Peat Restoration Team (TRGD) of South Sumatra as an initial initiation to follow up peat restoration that has been done to date. The Peat Restoration Team (TRGD) of South Sumatra needs to be developed to synergize the potential of various stakeholders. 


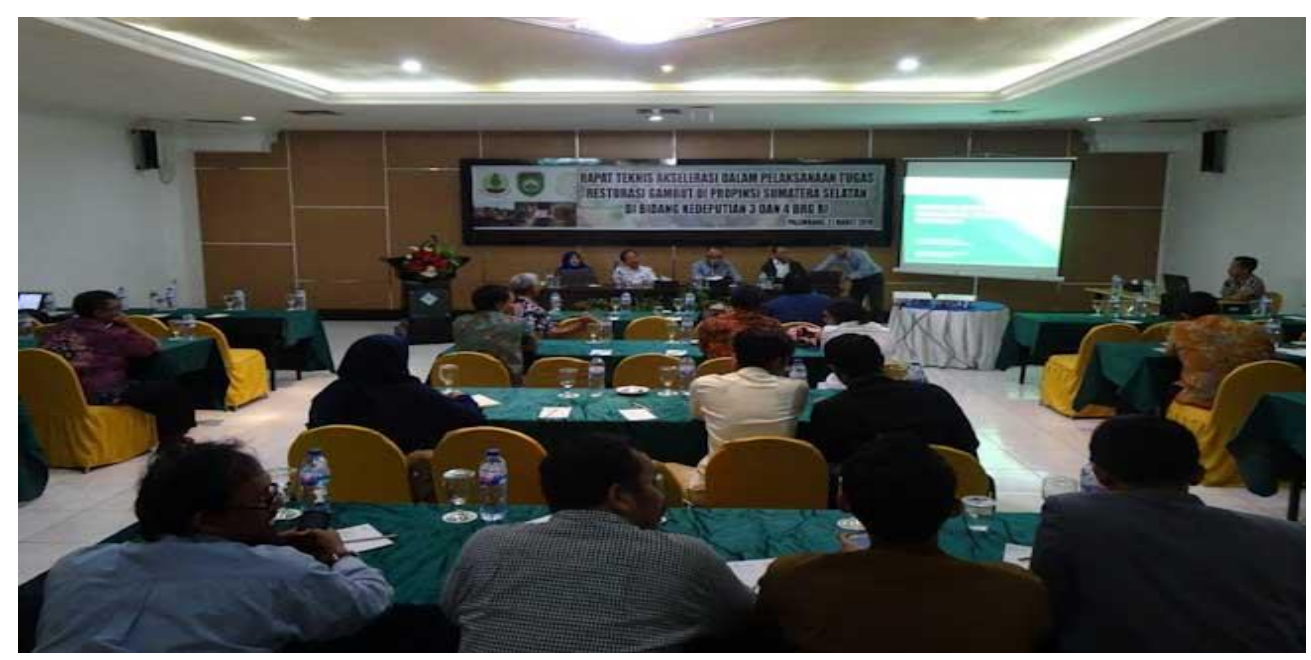

Fig.2. Technical Meeting of Acceleration in the Implementation of Peat Restoration Tasks in the Field of Declines 3 (three) and 4 (four) Peat Restoration Agency (BRG) of Indonesia Republic (RI).

Source: Communications And Information Agencies of South Sumatera Province

\section{Planning Collaborative Action}

Stakeholders or policymakers involved in the Acceleration of Peat Restoration Task agenda of the preparation of Education, Socialization, Participation and Peat Restoration Partnership activities as well as the plan of preparation of peat restoration research and development.

Head of Working Group Education and Socialization of BRG South Sumatra Region and Head of Sub- Working Group Education, Socialization and Training on The Third Division of BRG, conveyed the activities carried out in his exposure entitled Education, Socialization, Participation and Partnership Activities discussing among others about 1. Socialization of Peat Management at the District Level; 2. Peat Farmer Cross Visit, 3. Peat Farmer Field School; 4. Peat Protection Education for Elementary/Equivalent Students.

\section{Collaboration Planning Action (The Face)}

The Collaborative Action Plan has been approved with peat restoration implementation strategies, both from government agencies, the private sector and non-governmental organizations. The implementation planning of each strategy has been carried out globally, such as the socialization of Peat Management at the District Level, even to socialization to communities and community leaders, such as the socialization of Peat Management through the Forum of Peat Care Village.

This action plan is still in its early stages, as there has been no intensive and ongoing evaluation, such as identifying measurements of each process taken and determining steps to maintain the collaboration process to continue in the long term. 


\section{Conclusion}

Peat Collaboration in Ogan Komering Ilir Regency of South Sumatra Province is still underway at the trial stage and provides a preliminary basis for developing peat restoration policies in the future. There are barriers in the integration of ecosystem-based restoration activities is the difference of interest between restoration mandate holders (local governments and BRG) and land managers (communities and corporate concessions).

The Implementation and management of peat restoration require strategic collaboration for the development of peat restoration effectively, evenly, and sustainably. Strategies need to be developed so that each stakeholder has the same authority in determining peat restoration policies and implementation actions to follow current and future peat restoration.

Follow-up to the creation of permanent forums is necessary flexibly, by avoiding strict hierarchical structures or using organizations horizontally, to optimally accommodate and utilize potential stakeholders.

\section{References}

[1] BB Litbang SDLP, PETA LAHAN GAMBUT INDONESIA SKALA 1:250.000. 2011.

[2] F. Agus and I. G. M. Subiksa, Lahan Gambut: Potensi untuk Pertanian dan Aspek Lingkungan. 2008.

[3] Andriesse J. P, Nature and Management of Tropical Peat Soils. 1988.

[4] T. Sintesis et al., "Pemanfaatan Dan Konservasi Ekosistem Lahan Rawa Gambut Di Kalimantan," Pengemb. Inov. Pertan., 2008.

[5] Pemerintah Republik Indonesia, PERATURAN PRESIDEN REPUBLIK INDONESIA NOMOR 1 TAHUN 20162012 TENTANG BADAN RESTORASI GAMBUT. Indonesia, 2016, p. 16.

[6] A. Atika and A. B. Chandrabuwono, "PUBLIC SERVICE ADS. OF RESERVING PEAT FORESTS," INFORMASI, 2018, doi: 10.21831/informasi.v48i2.21835.

[7] C. Ansell and A. Gash, "Collaborative governance in theory and practice," J. Public Adm. Res. Theory, vol. 18, no. 4, pp. 543-571, 2008, doi: 10.1093/jopart/mum032.

[8] C. Ansell and A. Gash, "Collaborative platforms as a governance strategy," J. Public Adm. Res. Theory, vol. 28, no. 1, pp. 16-32, 2018, doi: 10.1093/jopart/mux030.

[9] B. D. Ratner, Collaborative governance assessment. 2012.

[10] K. B. R. GAMBUT and R. INDONESIA, "RENCANA STRATEGIS BADAN RESTORASI GAMBUT TAHUN 2016 - 2020.”p. 72, 2016.

[11] Center for International Forestry Research (CIFOR), The Criteria \& Indicators Toolbox Series. 1999. 